\title{
Confucian Ethics and the Spirit of Capitalism in Korea: The Significance of Filial Piety
}

\author{
Seok-Choon Lew, Woo-Young Choi, \\ and Hye Suk Wang
}

\begin{abstract}
Confucianism has been considered mainly to have had a negative influence on capitalistic development since Max Weber's theory on nonWestern societies became widespread. However, in this article, we champion the positive role of Confucianism and attempt to explain Confucianism as providing fundamental "significance" to social development by imbuing it with religious significance. We present the self-sacrificing work ethic and zeal for education that characterizes Confucianism as having become the foundation for Korea's economic growth. In particular, we examine the religious significance inherent in the Confucian value of "filial piety" and illustrate how the value came to be a powerful economic motivator during the process of industrialization. The religious tendency of filial piety, which attempts to "remember" and "represent" one's ancestors, acted as an important spiritual ethos in Korea's social development centered on economic growth. Filial piety did not stop at being an ethical standard; it was the fundamental basis for macrosocial dynamism that was closely linked to the development of capitalism in Korea. KeYwords: filial piety, remembrance and representation, familism, ancestor rites, Confucianism
\end{abstract}

MAX Weber (1930 [1920]) PRESENTED A REMARKABLE ANALYSIS OF THE social effects of religious values. In this sociological canon, Weber indicated that value orientation in Protestant Christianity contributed to the formation of a "diligent" work ethic, which was characteristic of modern Western capitalism. However, Weber went on to say that the spontaneous development of capitalism could not be found in non-Western societies for the reason that religious values imbuing economic motives for development were missing (Bellah 1957). A typical example cited was Confucian culture in China (Weber 1951 [1920]), but Korean society was not an exception (Tu 1991; Cha 1992; Park 1994). 
This raises questions on Weber's perspective of Confucianism and seeks theoretical foundations for an alternative argument involving the Confucian value of filial piety (xiao in Chinese, hyo in Korean, and kou in Japanese). The point of the argument is not criticism of Weber's theory of capitalism but of his interpretation of Confucianism. We suggest that the developmental significance of traditional values may be found by exploring the psychocultural effects of filial piety on the economic orientation of the people. Some may criticize that it is difficult to find economic impetus in filial piety-the former being the crystallization of instrumental rationality and the latter a purely normative virtue. Moreover, others would be skeptical about such efforts since the mere existence of an economic impetus in filial piety never guarantees spontaneous capitalistic development.

Paradoxically, however, support for this work is found in Weber's discussion on Western Europe. Although it is admitted that "Weber's last theory of capitalism" (Collins 1980) is predominantly institutional and involves a sequence of causal conditions, the emphasis on religious ideas and motivations that are specific to Western Europe is central. We do not deny that the development of capitalism is contingent not only on psychocultural orientations but also on various structural conditions and sociopolitical institutions. Nonetheless, within the context of these macrosocial determinants, there is still ample room for a causal relationship between cultural beliefs, work ethic, educational achievement, and-through those mechanisms-economic growth.

In this context, we explore in this article the "religious" aspect of filial piety to demonstrate the economic effects of this value orientation. In particular, filial piety is assumed to have a distinct and far-reaching religious significance that cannot be found in any other Confucian values (Taylor 1990). Filial piety is a mechanism specific to Confucianism that deals with the issue of death and immortality. In the process, filial piety presents itself as a latent but powerful link to economic motives by putting into practice characteristic rituals of "remembrance and representation" of ancestors. The economic motive concomitant with filial piety is also manifested in the formation of "familism" in Confucian culture. Filial piety generates strong normative pressures offering sociocultural grounds for "developmental," "successive," and "collective" representation and remembrance among family members. The ultimate intention of this work is to establish filial piety as a fundamental basis of the spirit of capitalism in Korea leading to a psychological mechanism from religious ethos to personal predisposition toward work and education. 


\section{Filial Piety: From Mortality to Eternity}

\section{Filial Piety as a Religion}

It is generally known that religion is the most basic and fundamental mechanism of consciousness confirming human existence. Although confirmation of existence has many dimensions, only religion extends human existence to immortality. The religious assurance of eternal life inevitably collides with the issue of death, because the death of a physical body is not only something to fear in itself but also an obstacle to eternal existence. In this sense, religion, which attempts to guarantee eternal life, must make the interpretation and handling of death its "hardcore" (Eliade 1985, 9-11).

The fact that Weber hesitated to categorize Confucianism as a religion carries important implications for this study. Weber noticed the absence of religious features in Confucianism such as the transcendent Absolute, messages of redemption, and "the Kingdom of a thousand years" (or Heaven). It was therefore natural for him to perceive Confucianism as nothing more than a secular ethic or as a colossal code of law, political principle, and social protocol for the cultured class (Weber 1951 [1920], 225). To Weber, Confucianism was devoid of religion's hardcore-that is, the need to extend existence into eternity by handling death in an appropriate manner. The only alternative left to Confucians whose existence failed to extend to eternity was an adamant attachment to this world. This is why Weber designated "the secular adaptation to this world" as a characteristic of Confucianism (Weber 1951 [1920], 350).

The problem with this is that Weber ultimately failed to grasp the religious nature of Confucianism, which can be found in the norm of filial piety. How does Confucianism, as a religion, deal with the issue of death and eternity? Let us examine the case of Christianity before answering this question. How Christianity deals with death and hence guarantees eternal life is well explained in Weber's work (1930 [1920]). Christianity presupposes the flawless will and action of the Absolute, which are manifested in evident objects. The "Kingdom of a thousand years," Heaven, is a spatial and temporal manifestation of eternal life, and this space and time are dehistoricized from a human perspective (Troeltsch 1958 [1912]). Human beings can extend their existence into eternity in the Kingdom of a thousand years by entering the gate to salvation, because the Kingdom is the ultimate refuge that the Absolute designed for humankind at the beginning of the world. 
However, the problem of salvation-all important to Christianswas solely the territory of priests of the Catholic Church before the Reformation. During the Middle Ages, under absolute church power and resulting corruption, some Christians began to protest the church's doctrine of salvation. They argued that the main criterion for salvation lay in faithfully following God's (or the Bible's) teachings in one's life. This new doctrine argued that anyone could gain salvation by leading a sinless life and diligently working in one's own calling. Thus Protestants worked diligently to become rich in this life, in part due to anxiety over uncertainty about gaining access to heaven and eternal life after death. Finally, after the Reformation, the goal of Protestantism became the accumulation of worldly goods through hard work and frugality-a sign that one is among the "saved." By means of working toward salvation-gaining eternal life-Europe was able to construct a diligent work ethic that became the "spirit of capitalism" (Weber 1930 [1920]).

However, unlike Christianity, Confucianism does not presuppose a priori teleology or divine will (Ching 1977). Instead, Confucians believes that the abstract universal principle that operates in nature and in the normative world constitutes and governs the real world (Keum1992, 215). The fundamental principles of Confucianism, such as the Way (Dao), the Principle ( $L i)$, and the Supreme Ultimate (Tai $J i)$, are basically depersonalized, and there is no divine plan for the afterlife. These fundamental principles are omnipresent in the cosmos, in nature, and in human beings as exemplars that constitute and normalize the world. They are external and transcendental — and at the same time immanent and internal- to humans (de Bary 1998, 40-41). It is humankind's natural and normative obligation to realize these principles by achieving a state of supreme good (Lee, Kwang-Kyu 1998, 262). Discussion on Confucianism thus far has revealed only the ethical or metaphysical aspect; its religious features have not been manifested yet.

The fundamental principle of $\mathrm{Li}$ retains the immortal essence that governs birth, extinction, and rebirth of nature and the universe (Hahm 1998, 262-266). Therefore, the determination of $\mathrm{Li}$ is not confined to the present world but rather extends to eternity. Indeed, the end of existence cannot stop Li's governance; rather, extinction is a natural manifestation of and an eternal return to $\mathrm{Li}$. Thus death is "relativized" here from the perspective of religious ontology. Biological death does not terminate a person's existence but makes it possible for that person to return to immortal and fundamental principles. Of course, this implies the following condition: human beings should make themselves one with Li through practices in the present world (Metzger 1977). Death is not the critical 
point that terminates a human's existence as long as this conditional imperative is fulfilled; rather, death is the beginning of eternal existence. From this we can comprehend the religious logic of Confucianism in the context of death and eternal existence.

Still, a simple but important question remains: the problem of abstraction and elitism of Confucianism in the context of the practice. As discussed earlier, there are only a constrained few who can overcome death and achieve everlasting existence. $\mathrm{Li}$, Dao, or Tai Ji is available to the religious virtuosi; the masses can only meet more minimal religious requirements (Hill 1973). ${ }^{1}$ This minimal religious requirement sheds light on the importance of practical norms of Confucianism, which prescribes standards for everyday life. It is this very context in which the Five Cardinal Relationships ( $W u$-Lun) are highlighted for commoners. Especially, among the Five Relationships, the practice of filial piety in the form of "affection between father and son" precedes all other relationships. ${ }^{2}$ In particular, filial piety after the death of parents is the zenith of a religious solution of Confucianism on the issue of death.

In Confucianism, filial piety is not merely a secular norm but a sublime religious imperative, and its essence is in "remembering" and "representing" one's ancestors, including one's parents. What then is the rationale for remembering and representing? Here lies the clue to the Confucian solution to death. Although this solution involves a rational return to one's nature in principle, as mentioned previously, it needs to be materialized in a tangible way so that commoners can follow and practice. That is, eternal existence of ancestors should be practically confirmed. Confucianism acquires religious persuasive power only when this demand is satisfied, and Confucianism finds the solution to this religious demand in remembrance and representation of ancestors. In other words, remembering and representing ancestors is a means to guarantee eternal existence.

This is why Confucianism puts so much emphasis on "ancestor worship." The eternal existence of ancestors is confirmed as long as their descendants remember and represent them. Conversely, eternal existence cannot be guaranteed without the descendants' remembrance and representation of their ancestors. As a result, lack of ancestor worship becomes a heretical act against the religious imperative of Confucianism. This explains why filial piety is so highly appreciated while filial impiety is so harshly reviled.

In effect, the biological constraint on existence is supplemented in Confucianism through remembrance and vicarious representation by one's descendants. One can be lifted up to eternal existence through remembrance 
and representation by one's children, their children, and successive descendants. Every human being without exception belongs somewhere in this ceaseless chain of memories and representations, thereby playing an important role that guarantees eternal existence. This is designated by Confucianism as the natural principle and categorically religious imperative. In this context, remembering and representing ancestors are the core practices of $\mathrm{Li}$ in Confucian metaphysics, and their execution takes the form of filial piety.

Through remembrance and representation of descendants, death is transformed into immortal life. This is why Confucianism puts more emphasis on filial piety toward the deceased over the living. Filial piety from this perspective is a pressing religious imperative that transcends mere secular norms, and this is the reason why it is placed first among the Five Cardinal Relationships. In such a way, Confucianism does not in fact lack a religious hardcore that manages death and guarantees eternal life. Rather, the hardcore is handled quite practically and rationally through the practice of filial piety. Not by relying solely on divine will but by appealing to humane voluntary practices does filial piety present a rational solution to the religious demand to address the issue of death.

\section{Economic Motives in Filial Piety}

All historical religions have "relativized" reality in principle, but they have also intervened in it directly or indirectly. Confucianism is not an exception. This is especially true in the Confucian world where the sacred and the secular are highly amalgamated (Park 1983) and where religion and politics are unified as well. ${ }^{3}$ Confucianism made forceful demands to reflect its religious orientation through the practice of filial piety (Sung 2005; Lee 1997; Hsu 1967). The practice of filial piety had to be "objectified" by a verifiable method, internally as well as externally. It is for this contextual reason that the demand to ritualize important events of life related to filial piety carries so much importance in Confucianism. These events are coming-of-age, marriage, funeral, and ancestor memorial ceremonies (Keum 2000; Kim, Deok-gyun 2004). Of course, no culture or religion can deny the importance of these ceremonies in general. However, it is only Confucianism that lends religious meaning to these rituals or institutionalized events. In other words, these ceremonies are concrete processes that deal with the religious hardcore of death and eternity in Confucianism.

The coming-of-age ceremony is a religious recognition of a new subject who will remember and represent. The marriage ceremony is a religious recognition of a biological union necessary for producing new 
subjects who will continue remembrance and representation. The funeral rites permit humans to overcome sorrow and allow the biological death of ancestors to be sublimated to eternity. Last, the ancestor memorial ceremony is a process of religious verification through which the descendants' imperatives of remembrance and representation are confirmed by periodic recall of ancestors who have entered eternity.

There is no question that these ceremonies or rituals are performed so that others can watch and see that descendants are performing the religious imperative conveyed in filial piety. Indeed, they are Confucianspecific institutionalized methods that confirm and verify the eternal lives of ancestors. As such, the practice of filial piety is connected directly to the assurance of religious citizenship, in terms of not only internal confidence but also external recognition of others. In this respect, there are powerful motives to objectify one's practice of filial piety in the Confucian world, ${ }^{4}$ which in turn depends on the practical cost of these ceremonies. As is generally known, this cost is formidable and requires considerable economic means. Especially costly are the memorial ceremonies for ancestors that are repeated annually throughout one's life, unlike once-in-a-lifetime ceremonies such as coming-of-age, marriage, and funeral ceremonies (Jeon 2008). Moreover, given that Confucian memorial rituals must be held in honor of four previous generations, the economic cost is considerable.

But, however high the cost, the imperative of ancestor memorials cannot be defied nor ritual costs curtailed at will, because it is the most central religious ritual among all ceremonies that ensure ancestors' existence. In fact, this is why the duty of "serving memorial ceremony" is so emphasized in Chosun-era Korea (Miyajima 1996). As such, the objectification of filial piety has become closely related to the assurance of an economic foundation. Practicing filial piety depends heavily on economic ability. Without a worldly fortune, commoners face a serious threat to the eternal life of their ancestors. Furthermore, expression of religious sincerity through "objectified rituals" is directly connected to heightened political as well as ideological justification, a unique phenomenon in Confucian society (Cho 1993). In this context, filial piety moves beyond the realm of "verification" to that of "competition." The focus is on who can better commemorate their ancestors and who can better represent their ancestors. ${ }^{5}$

Remembrance and representation therefore go beyond the mere religious dimension into the economic dimension by generating a desire to intensify the material foundations of a superior remembering and representing. In reality, the level of remembrance and representation cannot but differ among individuals and families, and the primary source of 
this differentiation is, of course, wealth. This competitive remembrance and representation strongly stimulates economic motives. By requiring economic competitiveness for better remembrance and representation of ancestors, filial piety rationalizes one's pursuit of economic wealth with the import of modernization and secularization. In return, the outcome of sincere economic activities resolves anxiety concerned with the question of "who can better represent one's ancestors." One's secular success provides visual evidence of one's filial piety for ancestors.

This process is very similar to how the Protestant ethic stimulates its believers to engage in secular activities for the glory of God. It can be said that Confucianism in Korean society has been functionally equivalent to Protestantism in Western societies. Although their functions are equivalent, their forms of practicing religious ethics are not the same. Protestants organized individualistic and atomized patterns of economic pursuit, as the emergence of the modern market itself reveals, whereas Confucianism took the form of collective responses to the need for wealth and thus generated different patterns of economic organization as well. In particular, the family became the primary agent of this rational and economic organization of filial piety.

\section{Filial Piety and Confucian Familism}

\section{Family in Confucianism}

It is difficult to say that familism is a phenomenon unique to Confucian culture or Korea. In all traditional societies, family functions as an absolute entity above individuals and other groups. When society is relatively undifferentiated, family is the most natural group that an individual depends on. And even today, familism is not a unique phenomenon, though perceptions and behavioral principles on familism vary across regions and cultures. In many third world countries, familism still functions as an important social phenomenon. ${ }^{6}$

We therefore need to examine the uniquely differentiating characteristics of Confucian familism (Hsu 1967). Although the general meaning of familism - that is, family-oriented perceptions and behavior - can be shared, its origin and historical context can differ among societies. This issue cannot be resolved until the mechanism that imbues Confucian familism with importance is articulated. In the end, this comes down to the formation of Confucian familism and its significance; the clue to its formation also lies in filial piety.

As discussed earlier, the religious function of filial piety lies in the subjugation of death and the assurance of eternal existence, and its practice 
is manifested in remembrance and representation. It is only natural that "family" assumes the role of the subject in this practice; the inclination to remember and represent ancestors is a natural response of those who are extensions of their ancestors. In fact, the phenomenon of remembrance and representation of ancestors occurs universally, including in Christian societies.

However, remembrance and representation in Christian society does not transcend the subjective dimension nor does it unite with religious orientation. In this sense, the meaning and status of family in Christian society is different from that in Confucian society. Rather, as Weber (1961 [1923], 335) appropriately pointed out, the motives for familial remembrance and representation seem to have been "relativized" by the religious program specific to Christianity. As a result, the meaning of family is reduced in Christianity, whereas in Confucian society, the meaning of family is extended beyond the socioeconomic dimension to the religious dimension. ${ }^{7}$ Specifically, family is the religious locus that guarantees eternal existence after death. Thus, in the Confucian world, family takes the place of church, or shrine, in remembering and representing ancestors. No other culture or religion puts more meaning on family than Confucianism, because the Confucian family carries the religious meaning of eternal life (DeVos 1998).

In such a way, biological as well as socioeconomic nature and religious prescription are integrated into the family in Confucianism. Family is the manifestation of the Heavenly principle that reflects nature and the moral imperative (Hahm 2004). As a result, family in Confucian society acts as a strategic unit in accessing religious citizenship, political power, social reputation, and economic resources. Individuals who are alienated from their families not only deviate from a deep social norm but also face substantial difficulties. The interests of individuals and those of their families cannot be separated in Confucian societies (Harris 1979).

Scarcity of resources heightened the emphasis on family in late Chosun Korea. The system of opportunity declined dramatically during the late Chosun dynasty, when class boundaries weakened and population pressure increased (Lee 1991; Jeong 1991), leading to intense social and economic competition. From the perspective of individual families, the crisis for survival threatened remembrance and representation of ancestors, and their strategic response was therefore urgent and acute.

Families' response to this crisis was "organizational integration." Primogeniture, solidification of rights to ancestral rites, establishment of consanguineous villages, publication of genealogy books and collected writings of ancestors, and erection of memorial halls and shrines are only some examples (Deuchler 1992). Consolidation of the right of primogeniture 
boosted the eldest son as the center of the family, after which the hierarchical unity of family was reorganized to increase the family's competitiveness. Likewise, the establishment of consanguineous villages reflected a strategic plan to reduce decisionmaking time and transaction costs by concentrating resources at a physical locality (Coase 1988 [1937]; Williamson 1973; Jacobs 1985). Families could share, confirm, and intensify remembrance and representation of that locality's ancestors through the publication of genealogy books and collected works of ancestors, the construction of memorial halls and shrines, and so forth.

Through these strategic practices, individuals' immersion in and devotion to the family were dramatically heightened as a means for survival under competitive conditions. The imperative endowed upon family by Confucianism in the normative domain was intensified by the politicoeconomic reality. The dismantling of the Confucian state by the Japanese, the liberation of Korea by US forces, and the devastating Korean War that divided the country only reinforced the trend. Through experience and learning about competition to survive, family became the supreme value as well as a practical reference point for every Korean. This is the historical origin of familism in Korea. However, subsequent developmental processes in modern Korean history only served to strengthen, rather than weaken, these trends.

\section{Modern Pressures for Better Representation}

Individuals are never independent or absolute in Korean society due to the domination of the culture of familism. Individuals exist as parts constituting the whole in the form of family - that is, as unity, not as independent units (Bell and Hahm 2003; Lew and Kim 2001) ${ }^{8}$ Likewise, individuals are a "totality of roles" in relation to the family and cannot have absolute independent meaning by themselves (Rosemont 1988). If this is the case, then what is the obligation of the parts to the unity of the family? Or what are roles of totality in relation to family?

These questions require further examination of the meaning of remembrance and representation. First, remembrance involves the offspring's conscious understanding of the physical appearance or lives of the parents during their lifetimes. And representation involves practicing to reveal the parents' characteristics during their lives through a specific form. These two are complementary and cyclical: the parents are represented through remembrance and remembered through representation. From an analytical perspective, however, representation encounters more threats than remembrance in modern contexts. 
The traditional form of representation (or ritual) has become obsolete in modern times. Still, representation is not abandoned, only expanded (Lee, Kwang-Kyu 1998, 259-261): representation is now manifested as revealing and extending the life of the parents by transferring that life to the child. Inevitably, representation is the offspring's practice by proxy on behalf of the dead parents, and if this meaning is extended, representation is the process through which the offspring lives the parents' lives on their behalf. This "proxy life" used to be objectified by institutionalized rituals of filial piety in traditional society, but the conditions for proxy life have mostly been destroyed in modern society. Today, representation needs to be practiced and confirmed throughout the offspring's entire life. Modern familism had to renew its operating mechanism while still preserving its essence of remembrance and representation. The modern religious drive for a better proxy life took new forms.

Korean modernization in the late twentieth century is widely acknowledged as a model of remarkable economic growth. No comparable experience can be found in world history, except in other Confucian countries. This has naturally generated much interest in its background, and unique Korean characteristics in particular have garnered much attention (Hamilton and Biggart 1988; Kuk 1999). Reinvigorated interest in Confucian familism is significant in this regard. Confucian discipline, collective devotion, familial mobilization of resources, and strong attachment to education have been pointed out as major forces behind Korea's economic growth (Pye 1985, 2000; Maison et al. 1980; Berger 1983; Hofheinz and Calder 1982; Kahn 1979; MacFarquhar 1980; Tai 1989; Tu 1996; Vogel 1991).

However, there is dissonance with respect to the broader socioeconomic causes of Korea's economic growth (Amsden 1989; Wade 1990; Fukuyama 1995; Bell and Hahm 2003; Shin and Chang 2003; Kim, Hyung-A 2004; Davis 2004) as well as the functional role that Confucianism might play. Few efforts have been made to explain how Confucianism drives economic development, and many arguments for its role do little more than point out how Confucianism and rapid growth managed to coexist. The missing link of how Confucianism might contribute to economic growth is not spelled out. Here, we link religiously prescribed remembrance and representation of ancestors to strengthened motives for children's education and labor ethics. In doing so, we articulate the internal psychological mechanism through which filial piety instills responsibilities of representation into family members.

It is well known that familism played a major role in the mobilization of resources in the course of modernization and economic growth in 
Korea (Park 1992). Mobilization, induced from outside, especially from the top (the state), was an important factor, but this does not explain work ethic or other mechanisms at the individual level. One source of this internal mobilization "from the bottom" was the desire not to lose the competition of remembering and representing ancestors. Efforts to represent ancestors based on remembrance imbue familial mobilization of resources with powerful religious motives. This phenomenon may be labeled "the economic effect of representation." Three mechanisms or pressures have significant consequences in the modern representing process.

The first is the pressure of developmental representation. As the traditional means of representation have been abolished, representation needs to be proved during the entire lifetime of the offspring according to the logic of proxy life. Does my life as the continuation of my parents' lives remember my ancestors well? Do I represent my ancestors well? These questions generate considerable anxiety. ${ }^{9}$ Moreover, in contrast to traditional society, the objective criterion to resolve this anxiety becomes vague. The only practical criterion in this regard is the achievement of a better life, an improvement in life over that led by the ancestors. If not, the life of the offspring cannot be recognized as proper and appropriate representation. Anxiety can only be escaped by improving one's life or at least maintaining the standard of living of one's ancestors. From the perspective of proxy life, a declining living standard is dereliction of obligation, a failure in representation, and therefore a failure in filial piety.

Development can be assessed using various standards. However, the first and foremost is economic. Although the goal of rising in the world and achieving fame encompasses political power, sociocultural authority, and other dimensions, the most obvious measure lies in economic success, because it is the foundation for familial gains in other areas. Economic improvement was not only the end goal but also the most objective criterion of developmental representation, especially in the early stages of industrialization. To achieve economic improvement, economic motives were highly stimulated by those who were engaged in proxy life. These motives were manifest in the first instance through labor effort. It is generally known that self-sacrificing labor was a somewhat unique characteristic of Korean industrialization, but there was an additional component that went beyond the general economic motives found in capitalist development; that component was religious pressure in the form of developmental representation.

The second modern pressure is that of successive representation. Developmental representation is not limited to one's lifetime. Remembrance 
and representation are imperative practices that should be continued by individuals of successive generations, thereby continually confirming the ancestors' existence. Individuals as part of the family lineage should remember and represent their ancestors and are also responsible for passing on remembrance and representation to the descendants. Each individual is a mediating link. Therefore, descendants, or children, have great importance. Children exist to remember and represent not only their immediate ancestors but also the ancestors before them. Reproducing and rearing a child is not a choice but an imperative in Confucianism; an offspring is not only my child but is also a child of my ancestors.

A child serves two functions in this sense: the means of representing me and my ancestors, and the new "subject" of representation that succeeds me. In the case of the former, a good way to practice the obligation of representation entrusted into my care is making it possible for my offspring to rise in the world and gain fame. In the case of the latter, my offspring is the new subject who will continue my obligation of representation in my stead. My offspring is endowed with the imperative obligation of representing the ancestors developmentally, as was I.

The important point is that satisfaction of these two meanings of representation depends on an economic foundation. First, economic means are necessary to provide an opportunity for children to rise in the world and become successful and to allow children to faithfully represent ancestors after one's death. The latter in particular demands extensive economic means. Although the primary responsibility lies with the children, the parents are charged with the no less momentous responsibility to provide the conditions in which the children can accede to the family lineage without discontinuity. On this point, the obligation reveals itself as pressure for successive representation (Sorenson and Kim 2004, 174).

Education is the best response to this successive pressure. Empowering children through education is the most apparent method to fulfill the obligation of representation. This is why in Korea enthusiasm for investment in children's education has been a constant for the past century (Chang 1989). Especially, the process of preparation for entrance to prestigious universities is a modern "objectified" ritual to reveal the religious preparation of "better representation" to others: that one's children are on the way to continue the succession. Investing in children can be nothing more than ensuring the continuance of representation, which reaffirms the importance of an economic foundation. This pressure of successive representation, along with the pressure of developmental representation, is the source of a powerful economic drive to succeed. 
The last modern pressure exerted by the religious effect of representation is that of collective representation. Subjects who represent ancestors exist as a collective whole. Descendants of ancestors encompass not only me but also those who share memories of those ancestors-that is, my siblings. Here we notice that the obligation of representation covers not only the hierarchical dimension of generations but also the horizontal dimension of brothers and sisters. Although individual brothers and sisters should represent their parents developmentally and successively, each representation contains the collectivity as a whole that cannot be separated from one another. Collective representation means that representation of ancestors should not be mine alone but ours as well.

Collectivity of representation contains a significant implication: sharing of the obligation of representation. Representation of ancestors does not end up in improving my own life but should also be proved through the lives of my brothers and sisters, thereby sharing the obligation by us all. In fact, levels of representation cannot but differ among brothers and sisters. A brother or sister's lack of economic capability can cause a crisis in collective representation. This pressure is no less considerable in that the possible failure of representation by individual family members could damage collective representation. There arises therefore a sense of responsibility - a collective responsibility among siblings- to guarantee successful representation.

Pressure for collective representation has a number of significant effects. Internally, tacit pressure acts among brothers and sisters to spur competition among them for economic advancement. They should stimulate and supervise each other's secular performance so that every family member can fulfill their totality of roles and contribute to collective representation. Externally, pressure for collective representation also spurs competition with other families and enhances the mutual aids for same family members in need. It is precisely in this context that the mutual aid given and received among brothers and sisters is appreciated and rewarded (Janelli and Janelli 1982, 104). Such a norm of mutual aid originated from the obligation of collective representation and consequently played the role of assurance on the familial level of representation.

These pressures help us explain a number of real-world circumstances. Self-sacrificing female factory workers supported their entire families, including brothers studying at college, out of their meager salaries in the 1960s and 1970s. Even low-income families would spend large amounts of money on exam preparation of their children so that they could climb up the educational ladder. Modernization in Korea would have been impossible if not for the high emphasis placed on economic 
success, with self-sacrificing, or sometimes self-exploiting (Ringmar 2005), input of labor, and dedicated concerns on children's education as pivotal mechanisms for economic growth.

\section{Continuities and Changes in Confucian Familism}

The religious characteristic implied in familism reveals its most patent and typical features in the context of traditional society, due to the prevalence of Confucianism in Chosun Korea. Does this mean that the religious foundation of familism no longer exists in modern Korea? Does familism have nothing to do with religious aspects in contemporary Korean society where secular principles dominate? Does the principle of filial piety as a religious imperative no longer operate through familism? Are the economic effects of familism therefore now muted?

The religious desire to remember and represent ancestors in the form of filial piety is the original foundation of familism in Korea. However, modern conditions that differ from traditional society drastically "secularized the religious orientation of Confucianism itself. Today few Koreans seem to accept Confucianism as a religion" (Koh 1996, 281). Confucianism as an institutionalized religion has disappeared in everyday life, and the deep religious meaning attached to filial piety cannot easily be perceived. Then how can Confucianism and filial piety still be seen as sources of economic growth?

At this point, attention should be paid to a telling article in a prominent foreign journal. According to Shim, "Korean Christians are Confucians in Christian cloaks" (Shim 1984). In the eyes of foreigners, Koreans are situated within the framework of foreign religion, particularly Protestant Christianity (Lee 1988), but in reality are living under the influence of Confucianism. ${ }^{10}$ Although Confucianism as a historically institutionalized religion has largely disappeared, Confucianism as an orientation that is internalized in everyday life still dominates modern Korean society. Confucianism is still alive not as an objectified religion but as a cultural ethos that has been adapted to modern conditions. In this sense, classification of Confucianism as a system of life and culture remains meaningful (Chan 1999, 212-213). Although the former has been weakened on the formal and institutional level, the latter has not.

Such Confucian legacy in modern Korea is clearly demonstrated in Table 1. It shows a cross-tabulation of "practicing ancestor rites" by "religion" based on a nationwide PPS (probability proportional to size) sample of 1,003 questionnaires surveyed in May 2000 (Shin et al. 2000). First, the table shows the distribution of religious belief in modern Korea: 
Table 1 Practice of Ancestor Rites by Religion, 2000

\begin{tabular}{lrlrrrrrrrr}
\hline Religion & \multicolumn{3}{c}{ Yes $^{\mathrm{a}}$} & \multicolumn{3}{c}{ No $^{\mathrm{a}}$} & \multicolumn{4}{c}{ Total $^{\mathrm{a}}$} \\
\hline Protestant & 90 & $(37.2)$ & $(12.2)$ & 152 & $(62.8)$ & $(56.7)$ & 242 & $(100)$ & $(24.1)$ \\
Catholic & 71 & $(78.0)$ & $(9.7)$ & 20 & $(22.0)$ & $(7.5)$ & 91 & $(100)$ & $(9.1)$ \\
Buddhism & 250 & $(88.7)$ & $(34.0)$ & 32 & $(11.3)$ & $(11.9)$ & 282 & $(100)$ & $(28.1)$ \\
Others & 16 & $(94.1)$ & $(2.2)$ & 1 & $(5.9)$ & $(0.4)$ & 17 & $(100)$ & $(1.7)$ \\
No religion & 308 & $(83.3)$ & $(41.9)$ & 63 & $(17.0)$ & $(23.5)$ & 371 & $(100)$ & $(37.0)$ \\
\multicolumn{1}{c}{ Total } & 735 & $(73.3)$ & $(100)$ & 268 & $(26.7)$ & $(100)$ & 1,003 & $(100)$ & $(100)$ \\
\hline
\end{tabular}

Source: Data from Shin, Kwang-Yeong et al. 2000.

Note: a. For each answer, the number of responses is followed by the row percentage (in parentheses), and then the column percentage (in parentheses).

Protestant (24 percent), Catholic (9 percent), Buddhist (28 percent), and no religion (37 percent). Distribution of religion in Korea per se indeed shows no sign of Confucian tradition at all. ${ }^{11}$ However, if you ask a question to the same sample whether they are practicing ancestor rites or not, 73 percent respond yes. In this important regard, about three-quarters of Koreans are found to be still Confucian. Especially people in the categories of "no religion" and "Buddhism" have the highest yes rate, reaching to almost 90 percent. And, even 78 percent in the "Catholic" category respond yes. The lowest yes category is, of course, Protestant, but the rate of Protestants practicing ancestor rites is still 37 percent. ${ }^{12}$ As far as ancestor rites are concerned, Korea is still predominantly Confucian. Indeed, as the journal article suggests, Korean Christians are Confucians in Christian cloaks.

Table 2 provides information on the future of religious orientation in Korea. The table is based on a survey that asked a sample of 319 young local primary and middle school students in 2008 whether they will practice ancestor rites when they grow up (Lee 2008, 221, 229). Surprisingly, the rates belonging to "won't" are only 14.2 percent and 7.0 percent for male and female students, respectively. The rest of them, including "don't know" and "no response," consist of 85.8 percent male students and 93.0 percent female, and they are found not to reject Confucian tradition of practicing ancestor rites when they grow up. Besides, there exist Confucian proactive portions of 63.6 percent male and 60.1 percent female students who manifest clearly that they will do the rituals in the future. And this trend shows no difference between male and female students.

Further survey evidence that modern Korea is still predominantly Confucian, as far as filial piety and ancestor rites are concerned, comes from a survey of housewives. An absolute majority of housewives, who 
Table 2 Youth's Opinion of Future Practice of Ancestor Rites, 2008 (percentage of respondents)

Do you think you will practice ancestor rites when you grow up?

\begin{tabular}{|c|c|c|c|c|c|c|c|c|c|}
\hline \multicolumn{2}{|c|}{ Will } & \multicolumn{2}{|c|}{ Won't } & \multicolumn{2}{|c|}{ Don't Know } & \multicolumn{2}{|c|}{ No Response } & \multicolumn{2}{|c|}{ Total $(\mathrm{N}=319)$} \\
\hline $\mathrm{M}$ & $\mathrm{F}$ & M & $\mathrm{F}$ & M & F & M & $\mathrm{F}$ & M (194) & $\mathrm{F}(125)$ \\
\hline 63.6 & 60.1 & 14.2 & 7.0 & 19.9 & 28.7 & 2.3 & 4.2 & 100 & 100 \\
\hline
\end{tabular}

Source: Data from Lee, Seung-Yon 2008, 221, 229.

Note: The sample is drawn from local (southeast region of Korea) students and is composed equally of 10th, 13th, and 15th graders: $\mathrm{M}=$ male; $\mathrm{F}=$ female.

make the most substantial "sacrifice" for ancestor rites in the form of cooking and serving, responds that the ritual is "necessary." Out of a sample of 249 housewives, living in the two southern coastal cities of Pusan and Yeosu, interviewed in September 2003 (Jung, Jung, and Kim $2004,137,148$ ), only 17 percent claimed that the ritual is unnecessary. On the other hand, those who think that the ritual is necessary make up 83.1 percent of the whole sample, including a strong 55 percent who responded "absolutely" (see Table 3).

The reality still witnessed today is nationwide migration of millions of Koreans heading for their hometowns on traditional holidays (Choosuk or Thanksgiving and Seol or Lunar New Year) to pay respect to their ancestors, and many rigidly adhering to interment burial despite serious lack of available land. ${ }^{13}$ Korea has a unique market where commodities of "filial piety tourism" or "filial piety insurance" for elderly parents are widespread. The habitual visits presidential candidates pay to their ancestors' tombs ahead of presidential elections show exactly the same context. Attendance at ancestors' memorial ceremonies is a fundamental appointment most Koreans cannot defy, and a sense of guilt accompanies nonattendance even without condemnation by others. Alternatively, Christian memorial services replace Confucian remembrance ceremonies. Although we may not take notice of the internalized religious nature of remembrance and representation of ancestors, it has become a habit of the heart for every Korean (Sorenson and Kim 2004, 171-174).

In sum, in the course of modernization, traditional means for remembering and representing have disappeared. Except for the memorial ceremony, all other objective means or rituals have disappeared and their absolute religious meaning abridged to a certain extent. Modernity in Korea deconstructed traditional forms of remembrance and representa- 
Table 3 Housewives' Opinion of Ancestor Rites, 2003

Do you think ancestor rites are necessary?

\begin{tabular}{cccccc}
\hline Absolutely & So-So & Not at All & Don't Know & No Response & Total \\
\hline $137(55.0)$ & $70(28.1)$ & $17(6.8)$ & $15(6.0)$ & $10(4.0)$ & $249(99.9)$ \\
\hline
\end{tabular}

Source: Data from Jung, Jung, and Kim 2004, 137, 148.

Notes: The sample is drawn from local housewives in Pusan (150) and Yeosu (100). Number of responses come first (percentages in parentheses).

tion. The need to renew these means of remembering and representing or to replace them with another form nonetheless persists; the abolition of traditional means is not an indication of an absence of desire or obligation to remember and represent. ${ }^{14}$

In the modernization process, the mode of remembrance and representation has been renewed or transformed from its constrained formsuch as memorial ceremonies - to a generalized form of "exaltation of the life of one's children." The great importance attached to education, which is a specific phenomenon in Confucian society, is an expression of a strong desire to realize this exaltation of life. A vignette by Janelli and Janelli $(2004,135)$ summarizes this transformation well:

In Naeari, the creation of an ancestral hall for collective rites was viewed as a simplification of ritual practices and, by implication, a curtailment of filial piety. ... Arguing against the creation of the hall, one elder proclaimed that ancestor rites were a form of filial piety. Those favoring the hall did not challenge this moral norm but chose instead to define it more broadly. They pointed out that by creating the hall, the lineage would no longer need the extensive land holdings that were used to finance all the separate rites at gravesites. Some of these ritual estates could then be sold to provide funds for the education of promising descendants, which would also be a form of filial piety, they maintained.

\section{Conclusion}

There have been many studies that have highlighted Confucian culture and familism as positive reasons for Korea's success. A central weakness of these studies is the failure to identify the mechanisms through which aspects of Confucianism and familism enabled success. We emphasize the significance of filial piety. As a religious ethos, filial piety internalizes responsibility for remembering and representing ancestors 
among Koreans in general, which transforms itself through familial practice into motives for economic success. The religious imperative of filial piety is the hidden source of self-sacrificing labor and adherence to education in Korea, and thereby we may label it as a Korea-specific or Confucian-specific "spirit" of capitalism..$^{15}$ It would not be an exaggeration to call the Korean economy of the last fifty years an economy of filial piety.

The main effects of the religious impetus to remember and represent ancestors are found in three sociocultural pressures: developmental, successive, and collective. ${ }^{16}$ With the strategy of the developmental state from the top, the economy of filial piety from the bottom has constituted the other side of the coin of economic development in Korea since the 1960s. Korean development in the 1960s and 1970s heavily depended on mobilization of human resources. Familial representation was decisive in channeling dedicated labor and education-obsessed parental concerns to the process of industrialization. Representation under conditions of abject poverty became "economic representation." From a macroperspective, it was effective in establishing a dedicated, disciplined, and educated workforce. Self-sacrificing labor coupled with educational enthusiasm (or obsession) was the central mode of the practice of economic representation.

The developmental state of Korea derived familial mobilization from the economy of filial piety, and successful economic growth was achieved through efficient distribution and management of that economy. "Developmental, collective, and successive representations" hold remarkable significance in this process. The state minimized the cost of social welfare by relying on familial mutual aid generated by these pressures of representation. Instead, the state appropriated the curtailed cost for construction of economic infrastructure, which consequently paved the way to maximize macroeconomic growth. Family-like affective ties or associations, mediated by school or local networks, internalized responsibility for one another as an ethos and were functionally connected with the mobilization mechanism of the developmental state (Lew, Chang, and Kim 2003).

Seok-Choon Lew is professor of sociology at Yonsei University. Recently, he has written extensively on affective networks in East Asia and developmental state, including an edited volume of his papers for a book, Confucian Capitalism and Affective Networks in Korea (forthcoming in Korean), and a chapter, "Korean Development Model: Lessons for Southeast Asia," in David Steinberg, ed., Korea's Changing Role in Southeast Asia (2010). 
Woo-Young Choi is assistant professor of sociology, Chonbuk National University, Korea. His research is mainly focused on Confucian theory and sociology of religion. His writings, including Social Capital in Korea: A Comparative Study on Traditional Society and Modern Society (coedited, in Korean), cover the Confucian path of modernization and the relationship between Confucianism and modernity in Korean society.

Hye Suk Wang is a PhD candidate in sociology at Yonsei University. Currently she is preparing a dissertation on the national health insurance program in South Korea and Taiwan that compares how family values in the two countries shape different welfare schemes. Her research focus is on culture and institutions in East Asia.

\section{Notes}

We would like to thank the 2009 Fulbright Senior Research Program for supporting Seok-Choon Lew's leave at the Graduate School of International Relations and Pacific Studies, University of California, San Diego, from September 2009 to February 2010, during which time he was able to complete this work. Thanks also go to Stephan Haggard, Jong-Sung You, and Ji-Hyeon Jeong for improving the quality of this article, which is a substantially revised version of our earlier paper in Korean published in HankukSahoehak (Korean Journal of Sociology) in 2005, 39, 6: 52-86.

1. These virtuosi are exemplary figures who are considered the ideal model in Confucianism (Hahm 1998, 2004). They are those who have mastered the religious solution of Confucianism by gaining knowledge through the investigation of objects and the cultivation of the mind (Taylor 1990, 39-52; de Bary 1998, 100-102). Realistically, however, this is limited to only a few.

2. Filial piety is considered the first virtue in Chinese culture. While China has always had a diversity of religious beliefs, filial piety has been common to almost all of them. This relationship was extended by analogy to a series of five relationships or five cardinal relationships (wulun): father and son, ruler and subject, husband and wife, elder and younger brother, friend and friend.

3. Fung Yu-lan (1952) estimates that the Confucian world is where the sacred and the profane are unified as one, and in this sense, Confucianism is the synthesized principle that encompasses religion and reality.

4. This is similar to Weber's thesis on Protestantism, in that Protestants are attached to the objectified evidence of wealth in order to subjugate tension and unrest as well as strengthen the subjective conviction of salvation (Weber 1951 [1920]).

5. The process of competitive diffusion of intensified clan rules on ancestor memorial services, the publication of genealogy books and collected works of ancestors, and the erection of ancestral memorial halls and shrines in the late Chosun dynasty can be viewed in this context (Deuchler 1992).

6. According to Putnam (1993), the sociocultural orientation of southern Italy can be explained from the perspective of familism as well.

7. Weber found a clue to kinship "relativization" in an incident recorded in Galatians about the symbolic significance of the "conference at Antioch." 
According to this record, St. Paul overcame the kinship exclusivity of St. Peter and tolerated uncircumcised Gentiles by agreeing to hold rituals and communion with the Gentiles. For Weber, this incident is a sign of progress made in modern Western history in which the familial (kin) boundary is crossed to advance into universalism (Weber 1961 [1923], 335).

8 . Family is the unity when compared to individuals. However, each family can be a part of a greater and more fundamental principle, the Heavenly Principle. As such, the worldview of Confucianism is constituted of links of unity and parts. In any case, those alienated from these links - that is, separate entitiescannot exist (Choi 1999).

9. "A lineage woman told us that her first son died in childhood, shortly after her husband's family had failed to perform a death-day rite for one of their ancestors. Someone later told her that omitting the rite had caused her child's death" (Janelli and Janelli 1982, 157).

10. An example of this can be "the Christian memorial service" in Korea (Sorenson and Kim 2004, 173). In fact, memorial services that mourn the dead are a phenomenon specific to Korean Christians and cannot be found in the Christian Bible or its doctrines. Korean Christians in general show a negative response to Confucian memorial rituals, but paradoxically, Christian memorial services practiced now have many implications, as they are Christian adaptations of traditional Confucian values.

11. The 2005 census, which includes "Confucianism" as a response category, reports: Protestant, 18.3 percent; Catholic, 10.9 percent; Buddhist, 23.1 percent; Confucian, 0.2 percent; other religion, 0.5 percent; and no religion, 46.5 percent (Korea National Statistical Office 2008, 583).

12. In Korea, it is generally admitted that Protestant orders have strictly banned Confucian memorial rites that require bows and sacrifices to the dead, while Catholic orders have maintained a moderate view on these rites (Lee 1988). This difference of missionary strategy creates a significant attitudinal gap between Protestants and Catholics toward the issue of Confucian ancestor rites. Catholics are more tolerant than Protestants. For example, one Protestant online newspaper reports that out of 100 lay believers, fifty-six think that practicing "traditional ancestor rite" is a serious problem since it is "idol worship" (www .unionpress.co.kr/news/print_paper.php?number=4676, accessed September 20, 2010). The same report describes twenty-six out of 100 believing it is no problem because it is just a traditional custom. However, Catholics show an opposing tendency: "The proportion of Korean Catholics who practice ancestor rite increased from 69.4 percent in 1987 to 88.0 percent in 1998" (Hankyoreh Daily, April 11, 1998).

13. Cremation has been considered to be a serious violation of filial piety in Confucianism.

14. Recently, a big academic conference was cohosted by the Korean Studies Advancement Center and the World Confucianism Festival Community to review and search for new forms and methods of Confucian ancestor rituals and to commemorate 600 years of Confucianism in Korea; this took place on September 16-17, 2010, at the Seoul Museum of History (Chosun Daily, September 
$15,2010)$. The conference attracted so much public attention that it turned out to be a standing-room-only event.

15. Gordon Redding (1990) and Souchou Yao (2002) applied similar logic to overseas Chinese capitalism.

16. This unexpectedly reminds one of the economization processes of religious ethics that transformed the Protestant desire for salvation into abstinent labor. In this sense, serious comparative studies of these two aspects are urgently required.

\section{References}

Amsden, Alice. 1989. Asia's Next Giant: South Korea and Late Industrialization. New York: Oxford University Press.

Bell, Daniel A., and Chaibong Hahm, eds. 2003. Confucianism for the Modern World. Cambridge: Cambridge University Press.

Bellah, Robert. 1957. Tokugawa Religion: The Cultural Roots of Modern Japanese Capitalism. New York: Free Press.

Berger, Peter. 1983. "Securality: East and West." In Cultural Identity and Modernization in Asian Countries: Proceedings of Kokugakuin University Centennial Symposium. Tokyo: Institute for Japanese Culture and Classics, Kokugakuin University.

Cha, Seong-hwan. 1992. "Neo-Confucianism and Private Ethics." In Sociological Understanding of Korean Religious Thoughts, ed. S. H. Cha, 44-110. Seoul: Munhakgwa jiseongsa. (In Korean)

Chan, Joseph. 1999. "A Confucian Perspective on Human Rights for Contemporary China." In The East Asian Challenge for Human Rights, ed. J. R. Bauer and D. A. Bell, 212-237. New York: Cambridge University Press.

Chang, Yun-Shik. 1989. "From Filial Piety to the Love of Children." In The World Community in Post-Industrial Society: Changing Families in the World Perspective, ed. Korean Christian Academy, 77-94. Seoul: Wooseok Publishing.

Ching, Julia. 1977. Confucianism and Christianity. Tokyo: Kodansha International. Cho, He-in. 1993. "Characteristics and Orders of a Rural Village in Chosun." In The Structure and Characteristics of Confucian Traditional Society, ed. Hanguk Jeongshin Munhwa Yeonguwon, 149-184. Seongnam: Hanguk Jeongshin Munhwa Yeonguwon. (In Korean)

Choi, Bong-young. 1999. "Neo-Confucian Perspective on Human Beings and Humanism." Dongyangaahoesasang 2: 31-77. (In Korean)

Coase, Ronald. 1988 [1937]. "The Nature of the Firm." Economica 4, reprinted in Ronald Coase. The Firm, the Market, and the Law, 33-55. Chicago: University of Chicago Press.

Collins, Randall. 1980. "Weber's Last Theory of Capitalism: A Systematization." American Sociological Review 45, 6: 925-942.

Davis, Diane, 2004. Discipline and Development: Middle Class and Prosperity in East Asia and Latin America. Cambridge: Cambridge University Press.

de Bary, Theodore. 1998. Asian Values and Human Rights: A Confucian Communitarian Perspective. Cambridge: Harvard University Press. 
Deuchler, Martina. 1992. The Confucian Transformation of Korea: A Study of Society and Ideology. Cambridge: Harvard University Press.

DeVos, George A. 1998. "Confucian Family Socialization: The Religion, Morality, and Aesthetics of Propriety." In Confucianism and the Family, ed. W. Slote and G. DeVos, 329-380. Albany: State University of New York Press.

Eliade, Mircea. 1985. "Homo Faber and Homo Religious." In The History of Religions, ed. J. M. Kitagawa, 1-12. New York: Macmillan.

Fukuyama, Francis. 1995. "Confucianism and Democracy." Journal of Democracy $6,2: 20-33$.

Fung, Yu-lan. 1952. A History of Chinese Philosophy. Princeton: Princeton University Press.

Hahm, Chai-bong. 1998. Post-Modern and Confucianism. Seoul: Nanam. (In Korean)

- 2004. "The Ironies of Confucianism." Journal of Democracy 15, 3: 93107.

Hamilton, Gary. 1985. "Why No Capitalism in China? Negative Questions in Historical Comparative Research.” Journal of Developing Societies 1-2: 187-211.

Hamilton, Gary, and Nicole Biggart. 1988. "Market, Culture and Authority: A Comparative Analysis of Management and Organization in the Far East." American Journal of Sociology 94: 52-94.

Harris, Christopher. 1979. "The Sociology of the Family: New Directions for Britain.” In Sociological Review Monograph 28, ed. C. Harris, 74-112. Chester, UK: Bemrose Press..

Hill, Michael. 1973. A Sociology of Religion. London: Heinemann.

Hofheinz, Roy, Jr., and Kent E. Calder. 1982. The East Asia Edge. New York: Basic Books.

Hsu, Francis. 1967. Under the Ancestor's Shadow. New York: Anchor Books.

Jacobs, Norman. 1985. The Korean Road to Modernization and Development. Urbana: University of Illinois Press.

Janelli, Roger, and Dawnhee Yim Janelli. 1982. Ancestor Worship and Korean Society. Stanford: Stanford University Press.

- 2004. "The Transformation of Filial Piety in Contemporary South Korea." In Filial Piety, ed. C. Ikels, 128-152. Stanford: Stanford University Press.

Jeon, Sang-in. 2008. "Social Capital in the Chosun Period: Networks, Linkages, and Solidarity of Two Upper Classes." In Social Capital in Korea: A Comparative Study on Traditional Society and Modern Society, ed. S. C. Lew et al., 75-104. Seoul: Baeksan. (In Korean)

Jeong, Jin-yeong. 1991. "The Formation and Social Functions of Clan Villages in Late Chosun." In Korean Historical Debate 21: Country Village Societies in Late Chosun, ed. Guksa Pyeonchan Wiwonhoe, 29-68. Gwacheon: Guksa Pyeonchan Wiwonhoe. (In Korean)

Jung, Bok-Mi, Hae-Ok Jung, and Eun-Sil Kim. 2004. "A Study on Ancestral Service Preparation and Sacrificial Consciousness of Housekeepers Living in the Pusan and Yeosu Area." Korean Journal of Culinary Research 10, 3: 135-154. (In Korean) 
Kahn, Herman. 1979. World Development: 1979 and Beyond. Boulder: Westview Press.

Keum, Jang-tae. 1992. "Gods in Confucianism.” In A Discovery of Confucius' Thoughts, ed. S. S. Yun, 211-230. Seoul: Mineumsa. (In Korean)

- 2000. Thoughts and Rituals in Confucianism. Seoul: Yemunseowon. (In Korean)

Kim, Deok-gyun. 2004. "Life and Death and Religious Services of Confucianism from the Perspective of Filial Piety." Hyohak Yeongu 1: 290-303. (In Korean)

Kim, Hyung-A. 2004. Korea's Development Under Park Chung-Hee: Rapid Industrialization, 1961-79. London: RoutledgeCurzon.

Koh, Byong-ik. 1996. Tradition and Transformation of East Asian History. Seoul: Munhakgwajiseongsa. (In Korean)

Korea National Statistical Office. 2008. Social Indicators in Korea. Seoul: Korea National Statistical Office.

Kuk, Min-ho. 1999. State-initiated Industrialization in East Asia and Confucianism. Gwangju: Jeonnam Daehakgyo Chulpanbu. (In Korean)

Lee, Hae-jun. 1991. "Studies on Confucian Academy and Rural Village in Late Chosun." In Korean Historical Debate 21: Country Village Societies in Late Chosun, ed. Guksa Pyeonchan Wiwonhoe, 3-28. Gwacheon: Guksa Pyeonchan Wiwonhoe. (In Korean)

Lee, Jung Young, ed. 1988. Ancestor Worship and Christianity in Korea. New York: Edwin Mellon Press.

Lee, Kwang-Kyu. 1997. Korean Family and Kinship. Seoul: Jipmoondang.

_. 1998. "Confucian Tradition in the Contemporary Korean Family." In Confucianism and the Family, ed. W. Slote and G. DeVos, 249-266. Albany: State University of New York Press.

Lee, Seung-hwan. 1998. Social Philosophical Reconsideration on Confucianism. Seoul: Goryeo Daehakgyo Chulpanbu. (In Korean)

Lee, Seung-Yon. 2008. "A Review on Traditional Propriety Education in Elementary and Middle School." Journal of Moral Education in Primary Schools 28: 216-238. (In Korean)

Lew, Seok-Choon, Mi-hye Chang, and Tae-eun Kim. 2003. "Affective Networks and Modernity: The Case of Korea." In Confucianism for the Modern World, ed. D. Bell and C. B. Hahm, 210-217. Cambridge: Cambridge University Press.

Lew, Seok-Choon, and Tae-eun Kim. 2001. "Development of Township-Village Enterprises and the Re-institutionalization of the Family in China." Global Economic Review 30, 4: 83-111.

MacFarquhar, Roderick. 1980. "The Post-Confucian Challenge." The Economist, February 9, 67-72.

Maison, Edward, Kim Manje, Dwight Perkins, Kim Kwang Suk, and Dadid Cole, eds. 1980. The Economic and Social Modernization of the Republic of Korea. Cambridge: Harvard University Press.

Metzger, Thomas. 1977. Escape from Predicament: Neo-Confucianism and China's Evolving Political Culture. New York: Columbia University Press. 
Miyajima, Hiroshi. 1996. Two Upper Classes of Korea: In Search of Historical Substances. Seoul: Gang. (In Korean)

Park, Hee. 1992. "Organizational Operation and Labor Relations in Big Korean Corporations: A Study on the Effects of Familism.” PhD diss., Department of Sociology, Yonsei University. (In Korean)

Park, Seong-hwan. 1994. "Religion Development and Acculturation in Korea: Focused on Max Weber's Studies.” Hanguk Sahoehak 28: 53-84. (In Korean)

Park, Young-shin. 1983. "Structural Perception on Korean Traditional Society." In Structure and Theory on Modern Society, 119-146. Seoul: Iljisa. (In Korean)

Putnam, Robert. 1993. Making Democracy Work: Civil Traditions in Modern Italy. Princeton: Princeton University Press.

Pye, Lucian W. 1985. Asian Power and Politics: The Cultural Dimensions of Authority. Cambridge: Harvard University Press.

- 2000. “'Asian Values': From Dynamics to Dominoes?" In Culture Matters: How Values Shape Human Progress, ed. S. P. Huntington and L. E. Harrison, 244-255. New York: Basic Books.

Redding, Gordon. 1990. The Spirit of Chinese Capitalism. London: Walter de Gruyter.

Ringmar, Erik, 2005. Surviving Capitalism: We Learned to Live with the Market and Remained Almost Human. London: Anthem Press.

Rosemont, Henry. 1988. "Why Take Rights Seriously? A Confucian Critique." In Human Rights and the World's Religions, ed. L. S. Rouner, 176-182. Notre Dame: University of Notre Dame Press.

Shim, Jae-Hoon. 1984. "Phenomenon of the Cross." Far Eastern Economic Review $124,16$.

Shin, Jang-sup, and Ha-joon Chang. 2003. Restructuring Korea Inc. London: Routledge.

Shin, Kwang-Yeong, et al. 2000. Survey on Democracy and Traditional Beliefs, Korea Social Science Data Archive (KOSSDA, data \# A1-2000-0003). Available at www.kossda.or.kr (accessed September 24, 2010).

Sorensen, Clark, and Sung-Chul Kim. 2004. "Filial Piety in Contemporary Urban Southeast Korea: Practices and Discourse." In Filial Piety, ed. C. Ikels, 153181. Stanford: Stanford University Press.

Sung, Kyu-Taik. 2005. Care and Respect for the Elderly in Korea. Seoul: Jimoondang.

Tai, Hung-chao, ed. 1989. Confucianism and Economic Development: An Oriental Alternative? Washington, DC: Washington Institute Press.

Taylor, Rodney. 1990. The Religious Dimensions of Confucianism. Albany: State University of New York Press.

Troeltsch, Ernst. 1958 [1912]. Protestantism and Progress: A Historical Study of the Relation of Protestantism to the Modern World (translated by W. Montgomery). Boston: Beacon Press.

Tu, Wei-Ming. 1996. Confucian Traditions in East Asian Modernity: Moral Education and Economic Culture in Japan and the Four Mini-Dragons. Cambridge: Harvard University Press. 
Tu, Wei-Ming, ed. 1991. The Triadic Chord: Confucian Ethics, Industrial East Asia and Max Weber. Singapore: Institute of East Asian Philosophies, National University of Singapore.

Vogel, Ezra. 1991. The Four Little Dragons. Cambridge: Harvard University Press.

Wade, Robert. 1990. Governing the Market: Economic Theory and the Role of Government in East Asian Industrialization. Princeton: Princeton University Press.

Weber, Max. 1930 [1920]. The Protestant Ethic and the Spirit of Capitalism (translated by T. Parsons). New York: Scribner.

- 1951 [1920]. The Religion of China (translated by H. H. Gerth). New York: Free Press.

—. 1961 [1923]. General Economic History (translated by F. H. Knight). New York: Collier.

Williamson, Oliver. 1973. Markets and Hierarchies: Analysis and Antitrust Implications. New York: Free Press.

Yao, Souchou. 2002. Confucian Capitalism. London: RoutledgeCurzon. 